therapy facilitates healing of chronic foot ulcrers in patients with diabetes. Diabetes Care 2010; 33: $998-1003$

6. Dương Văn Hải (2017). Đặc điểm lâm sàng, hình ảnh chụp cắt lớp vi tính sọ não ở bệnh nhân nhồi máu não trước và sau điêu trị bằng oxy cao áp tại viên y hoc biển năm 2016-2017. Published online 2017.

7. Lể Thị Hồng (2017). Đặc điểm lâm sàng, cận lâm sàng và kết quảđiều trịnhồi máu não cấp bằng liêu pháp Oxy cao áp tai viển y hơc biển.

8. Chen-Yu Chen, Rw W, Nw T, et al.Increased circulating endothelial progenitor cells and improved short-term outcomes in acute noncardioembolic stroke after hyperbaric oxygen therapy.J Transl Med. 2018;16(1). doi:10.1186/ s12967-018-1629-x

\title{
BIẾN CHỨNG SỚM SAU CAN THIỆP VÕ̃ PHỒNG ĐỘNG MACH CHỦ NGỰC: NHÂN MộT TRƯỜNG HỢP VÀ NHÌN LẠI Y VĂN
}

\author{
Nguyễn Tùng Sơn ${ }^{1,2}$, Nguyễn Hữu Phong ${ }^{1}$, Phùng Duy Hồng Sơn ${ }^{1,2}$
}

\section{TÓM TẮT}

Võ phồng động mạch chủ xuống là bệnh lý hiếm gặp nhưng rất nặng nề. Phẫu thuật trước đây là tiêu chuẩn vàng trong điều trị bệnh lý này với tỷ lệ biến chứng và tử vong cao. Ngày nay phương pháp can thiệp nội mach đã phát triển và dần thay thế phẫu thuật kinh điển với kết quả tích cực làm giảm tỷ lệ biến chứng và tử vong và trở thành phương pháp điễu trị chính hiện nay. Tuy nhiên, phương pháp này vẫn có những mă̆t hạn chế và các biến chứng đặc thù. Tại Bệnh viện Việt Đức, chúng tôi đã áp dụng phương pháp này trong nhiếu năm qua. Chúng tôi báo cáo một trường hợp tử vong sau can thiệp nội mạch điều trị vỡ phồng động mạch chủ xuống, đồng thời nhìn nhận laai y văn về những biến chứng sớm của kỹ thuật này.

Tư khóa: Phồng động mạch chủ xuống; phồng động mạch chủ vỡ; can thiệp nội mạch.

\section{SUMMARY}

EARLY COMPLICATIONS AFTER ENDOVASCULAR TREATMENT OF RUPTURED DESCENDING THORACIC AORTIC ANEURYSM: A CASE REPORT AND LITERATURE REVIEW

Ruptured descending thoracic aortic aneurysm (rDTAA) is a rare but serious disease. Open surgical repair was previously the gold standard in treatment which is associated high morbidity and mortality rates. Endovascular thoracic aortic aneurysm repair (TEVAR) have developed with lower morbidity and mortality compared with surgery. However, TEAVR has its own limitations and is still a high-risk method. At Viet Duc University Hospital, we have applied this method for many years. We report a case of death following TEAVR for rDTAA, and review the literature with focusing on early complications of this technique.

\footnotetext{
${ }^{1}$ Bệnh viện Hữu Nghi Việt Đức

${ }^{2}$ Trường đại học Y Hà Nội

Chịu trách nhiệm chính: Phùng Duy Hồng Sơn

Email: hongsony81@yahoo.com

Ngày nhận bài: 17.5.2021

Ngày phản biện khoa học: 29.6.2021

Ngày duyệt bài: 15.7.2021
}

Key words: Descending thoracic aortic aneurysm; Ruptured aortic aneurysm; Endovascular intervention.

\section{I. ĐĂTT VẤN ĐỀ}

Vỡ phồng động mạch chủ ngực đoạn xuống (rDTAA) hiếm gặp nhưng là một tình trạng cấp cứu rất nă̆ng nề với tỷ lệ biến chứng và tử vong $\mathrm{cao}^{1}$. Trước đây, phẫu thuật qua đường mở ngực là tiêu chuẩn vàng trong điều trị, tuy nhiên kết quả sau mổ thường rất kém ${ }^{1}$. Nhiêu nghiên cứu chỉ ra tỷ lệ tử vong sớm trong vòng 30 ngày đâuu sau phầu thuật từ $20-50 \%{ }^{1}$. Phương pháp can thiệp nội mạch (TEVAR) đã ra đời và phát triển nhanh chóng trở thành phương pháp điều trị chính hiện nay đối với rDTAA ${ }^{2,3}$. Những ưu điểm nổi bật của kỹ thuật này có thể kể đến như ít xâm lấn, có thể tiến hành nhanh chóng, thời gian thực hiện ngắn và hạn chế mất máu². Kỹ thuật đã cho thây tính hiệu quả, làm giảm tỷ lệ biển chứng và tử vong so với phẫu thuật và có thể áp dụng thành công cả với những bệnh nhân không phù hợp phẫu thuật $t^{1,2}$. Dù vậy, can thiệp nội mạch với rDTAA vẫn là một phương pháp điều trị có nguy cơ cao với tỷ lệ tử vong sớm khoảng 16 - 19\% $\%^{1,4}$. Tại Bệnh viện Việt Đức, chúng tôi đã áp dụng phương pháp điều trị này trong nhiêu năm qua. Chúng tôi báo cáo một trường hợp tử vong sau can thiệp nội mạch điều trị rDTAA, đồng thời nhìn nhận lại $y$ văn về những biến chứng sớm của kỹ thuật này.

\section{CA LÂN SÀNG}

Bệnh nhân nữ 78 tuổi, được chuyển tới phòng cấp cứu của Bệnh viện Hữu nghị Việt Đức (BV Việt Đức) từ tuyến dưới do đau ngực trái đột ngột lan sau lưng kèm khó thở nhiều từ trước đó 2 ngày. Bệnh nhân (BN) có tiền sử tăng huyết áp 2 năm - có điều trị nhưng không rõ loại thuốc, huyết áp động mạch cao nhất khoảng 190/90 $\mathrm{mmHg}$, tiểu đường nhiều năm - có điều trị nhưng không rõ loại thuốc. Khám lâm sàng lúc 
vào viện: bệnh nhân tỉnh, tiếp xúc tốt, huyết động tạm ổn định (mạch 110 lần/phút, huyết áp động mạch $100 / 60 \mathrm{mmHg}$ ); xét nghiệm máu: hematocrit- $27 \%$, bạch câuu tăng cao- $25 \mathrm{G} / \mathrm{L}$, suy thận với ure $20 \mathrm{mmol} / \mathrm{L}$ và creatinine $240 \mu \mathrm{mol} / \mathrm{L}$, có Troponin $T$ tăng $145 \mathrm{ng} / \mathrm{L}$, đường máu tăng rất cao $26 \mathrm{mmol} / \mathrm{L}$. Trên X-quang ngực thẳng quai ĐMC và ĐMC xuống giãn to, mờ lan tỏa phế trường phổi trái (Hình 1-1). Siêu âm qua thành ngực: nhiều dịch máu khoang màng phổi trái, khổng có hở van $Đ M C$, chức năng tâm thu thất trái còn bù. Trên phim chụp cắt lớp vi tính đa dãy (MSCT) phát hiện hình ảnh hai túi phình ĐMCN xuống: 1 túi phình vị trí ngay đoạn đầu ĐMC xuống, cách chỗ xuất phát độngh mạch (ĐM) dưới đòn trái $2 \mathrm{~cm}$, kích thước $45 \times 60 \mathrm{~mm}$, đã võ gây tràn máu màng phổi + xẹp hoàn toàn phổi trái; túi phình thứ 2 cách ĐM dưới đòn trái $10 \mathrm{~cm}$ kích thước $13 \times 18 \mathrm{~mm}$ và xơ vữa rải rác ĐMC xuống (Hình 1-2,3,4).

Hội chẩn nhóm động mạch chủ bao gồm bác sĩ nội tim mạch can thiệp, bác sĩ ngoại tim mạch, bác sĩ gây mê, bác sĩ hồi sức tim mạch hội chẩn và đi đến kết luận: Không có chỉ định mổ mở kinh điển do nguy cơ tử vong rất cao, toàn trạng quá nặng, quyết định can thiệp đặt stent graft ĐMC xuống, mặc dù vẫn có nguy cở rủi ro cao.

Với chẩn đoán: Võ̃ phồng ĐMC xuống gây tràn máu khoang màng phổi trái; trên $\mathrm{BN}$ tăng huyết áp + đái tháo đường type II + suy thận độ III, $B N$ được chuyển vào đơn vị hồi sức tích cực tim mach và chuẩn bi các phương án can thiếp cấp cứu. Trong quá trình theo dõi tại đơn vị hồi sức, BN khó thở nhiều (thở ôxy 5 lít/phút), đường huyết cao liên tục dù đã kiểm soát bằng insulin truyền tĩnh mạch (TM), huyết động không ổn định (huyết áp ĐM xâm lấn 80-90/50-60 $\mathrm{mmHg}$ với thuốc vận mạch dopamin), tiểu ít, suy thận tăng (ure/creatinin $=22 / 327$, mức lọc cầu thận $13 \mathrm{ml} /$ phút $/ 1,73 \mathrm{~m} 2 \mathrm{da}$ ), mất máu (hematocrit tiếp tục giảm dưới $27 \%$, phải truyền 2 đơn vị máu, bạch cầu tăng cao $25 \mathrm{G} / \mathrm{L}$ ). Theo thang điểm EuroSCORE II, nguy cơ tử vong của bệnh nhân lên tới 45,24\%.

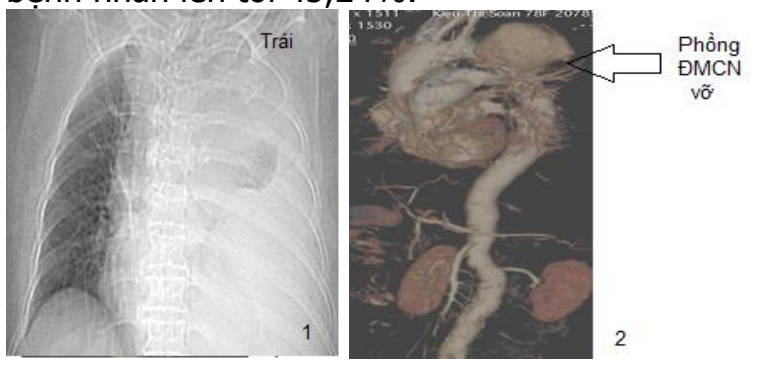

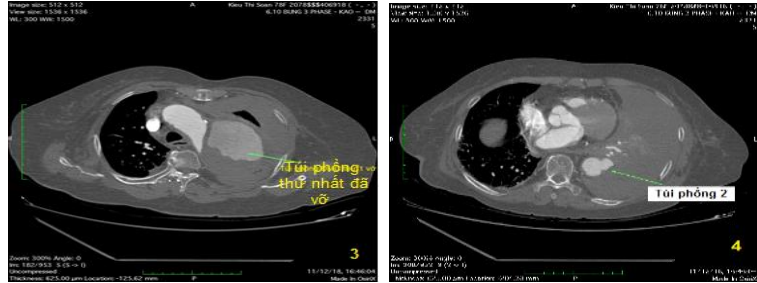

Hình1: Hình ảnh X-quang ngức và MSCT ngức trước can thiềp

BN được tiến hành can thiệp nội mạch cấp cứu sử dụng stent graft ĐMCN của hãng

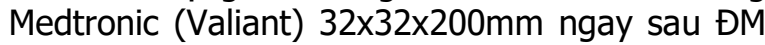
cảnh chung trái - che gốc ĐM đưới đòn trái. Chụp lại kiểm tra stentgraft thông tốt, hai ĐM cảnh thông tốt, không có thoát thuốc, không có hình ảnh thoát thuốc vào cả hai túi phình (Hình 2). Sau khi can thiệp ổn định, do máu màng phổi trái quá nhiều - ảnh hưởng đến hồi sức hô hấp, nên đã quyết định mở ngực nhỏ bên trái lấy máu cục khoang màng phối (khoảng 2000 gram). Tổng thời gian can thiệp là 4 giờ 30 phút.

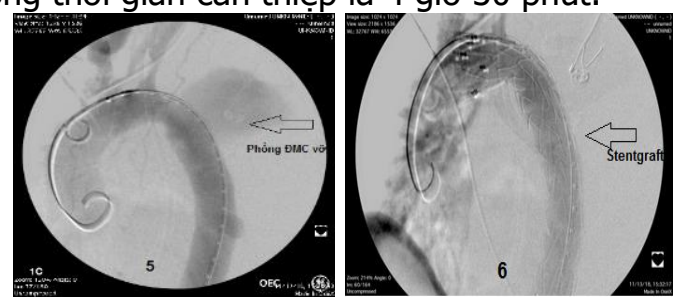

Hình 2. Chụp ĐMC ngức trước (5) và sau can thiệp (6)

BN tiếp tục được điều trị tại đơn vị hồi sức tim mạch, với tình trang tỉnh táo, kích thích nhe, không yếu liệt chi, dẫn lưu màng phổi trái ra ít, huyết động ổn định hơn, giảm dần được thuốc trợ tim, trao đổi phổi tăng, nước tiểu được tốt hởn. BN tiếp tục được hồi sức tích cực, thở máy và theo dõi sát liên tục 24/24. Xét nghiêm máu sau can thiệp: đường máu kiểm soát tốt hơn, chức năng thận có cải thiện (ure/creatinin giảm 22/272), hematocrit không tụt (28\%). Dự kiến sẽ rút ống nội khí quản nếu đủ tiêu chuẩn.

Tới thời điểm sau can thiệp 18 giờ, $\mathrm{BN}$ đột ngột tụt huyết áp, nhợt trắng, mạch chậm dần rồi ngừng tim, hôn mê, dẫn lưu màng phổi trái ra máu đỏ số lượng nhiêu (trên $1000 \mathrm{ml})$. Chẩn đoán tạm thời: võ̃ tái phát khối phồng ĐMC hoặc lóc ĐMC ngược dòng thành type Stanfort $A$. Tất cả các biện pháp cấp cứu hiện đại nhất đã được triển khai trong hai giờ liên, song tim chỉ đập rời rạc rồi lại ngừng. $B N$ được xác định là tử vong.

\section{BÀN LUẬN}

Võ phồng $\mathrm{DMC}$ ngực đoạn xuống (rDTAA) chiếm khoảng $30 \%$ trong võ phồng ĐMC ngực ${ }^{5}$, 
mổ mở cấp cứu là phương pháp điều trị kinh điển, tuy nhiên các kết quả sau mổ cho thấy tỷ lệ biến chứng và tử vong $\mathrm{CaO}^{1}$. Điều trị thành công rDTAA bằng TEVAR được Semba và cộng sự công bố đầu tiên năm $1997^{4}$, kể từ đó, phương pháp này đã có nhiêu sự phát triển vượt bậc để trở thành một giải pháp chính trong điều trị. So với phẫu thuật kinh điển, TEVAR đã cho thấy nhiêu ưu điểm nổi bật: là phương pháp xâm lấn tối thiểu, thời gian triển khai và thời gian tiến hành nhanh, có thể thực hiện với gây tê tại chỗ, gây tê vùng hoặc gây mê, hạn chế được các biến chứng liên quan đến mổ mở..., vì thế có thể được chỉ định cả với những bệnh nhân không phù hợp phẫu thuật ${ }^{2}$. Nhiều nghiên cứu cho thấy tỷ lệ biến chứng và tử vong sau TEVAR thấp hơn so với phẫu thuật kinh điển ${ }^{1,4,5}$, và xu hướng hiện điều trị rDTAA đã chuyển dần về phương pháp này².

Tuy nhiên, TEVAR cũng có những hạn chế riêng: Chất lượng vùng đặt (landing zones) là một yếu tố quan trọng được đặt ra khi định lựa chọn phương pháp này. Yêu cầu được đặt ra là vùng đặt ở đầu gần và đầu xa thường cần có độ dài tối thiểu $2 \mathrm{~cm}^{2}$, với những tổn thương sát quai động mạch chủ (vùng đặt có thể liên quan đến vùng 1 và vùng 2 của cây động mạch chủ), sẽ cần có kễ hoạch tưới máu các nhánh mạch (hybrid) như bắc cầu cảnh dưới đòn trái hay chuyển vị các nhánh mạch này ${ }^{2}$. Những trường hợp hệ mạch vôi hóa nhiều, đặc điểm giải phẫu khó tiểp cận, có các bệnh lý mồ liên kết, thường không phù hợp TEVAR ${ }^{2}$.

Trong trường hợp lâm sàng của chúng tôi, vị trí túi phình thứ nhất võ cách ĐM dưới đòn trái $20 \mathrm{~mm}$, túi phình thứ 2 cách $100 \mathrm{~mm}$. Tuy nhiên, do bệnh nhân này không có tiền sử dùng động mạch vú trong trái (để bắc câuu chủ - vành), đoạn ĐMC cần can thiệp < 200mm, ĐM đốt sống trái thiểu năng so với bên phải, nên chúng tôi quyết định can thiệp đặt stent graft vào vị trí ngay sau ĐM cảnh chung trái (chiêu dài đoạn an toàn $>20 \mathrm{~mm}$ ) và che phủ động mạch dưới đòn trái, để có được vùng đặt thuận lợi, không cần thiết bắc câu ĐM cảnh - ĐM dưới đòn trái ngay trong cấp cứu để giảm thời gian can thiệp. Đường kính ĐMC đoạn quai /2lân đo là 30 và $31 \mathrm{~mm}$, nên chúng tôi quyết định sử dụng stentgraft của hang Medtronic (Valiant) đường kính stent là $32 \times 32 \mathrm{~mm}$ và chiều dài $200 \mathrm{~mm}$ để che phủ toàn bộ tổn thương. Kết quả chụp kiểm tra ĐMC ngay sau bung stent graft thuận lợi.

Dù đã làm giảm đáng kể tỷ lệ biến chứng và tử vong so với phẫu thuật kinh điển, TEVAR vẫn là một phương pháp nguy có nguy cơ cao ${ }^{1}$.

Bảng 1. Các biến chứng sớm và tử vong sớm sau TEVAR trong các nghiên cứu.

\begin{tabular}{|c|c|c|c|c|c|}
\hline Biến chứng sớm & $\begin{array}{c}\text { Minami }^{1} \\
(n=23)\end{array}$ & $\begin{array}{c}\text { Jonker }^{4} \\
(n=143) *\end{array}$ & $\begin{array}{c}\text { Hammo }^{5} \\
(\mathrm{n}=140)^{*}\end{array}$ & $\begin{array}{c}\text { Etienne }^{6} \\
(\mathrm{n}=25)\end{array}$ & $\begin{array}{c}\text { Trân Q. Tiến } \\
(\mathbf{n}=\mathbf{3 1})\end{array}$ \\
\hline Biến chứng nội sọ & $626,1 \%)$ & $5 / 123(4,1 \%)$ & $20 / 136(14,7 \%)$ & $3(12 \%)$ & $3(10,3 \%)$ \\
\hline Liệt tủy & $2(8,7 \%)$ & $4 / 130(3,1 \%)$ & $13 / 136(9,6 \%)$ & $2(8 \%)$ & $2(6,8 \%)$ \\
\hline Biến chứng hô hấp & $7(30,4 \%)$ & & $5 / 136(3,7 \%)$ & - & $2(6,8 \%)$ \\
\hline Biến chứng tim & $1(4,3 \%)$ & $5 / 142(3,5 \%)$ & $5 / 136(3,7 \%)$ & - & $6(20,6 \%)$ \\
\hline Suy thận & $2(8,7 \%)$ & - & $5 / 136(3,7 \%)$ & - & $0(0 \%)$ \\
\hline Lóc ngược type $A$ & $1(4,3 \%)$ & - & & - & - \\
\hline Endoleak & $417,4 \%)$ & $10 / 90(11,1 \%)$ & $30 / 136(22,1 \%)$ & $8(32 \%)$ & $6(20,6 \%)$ \\
\hline Tử vong 30 ngày & $1(4,3 \%)$ & $27 / 143(18,9 \%)$ & $29 / 140(20,7 \%)$ & $9(36 \%)$ & $9(31 \%)$ \\
\hline
\end{tabular}

(*) nghiên cứu tổng hợp đa trung tâm

Những biến chứng sớm sau TEVAR điêu trị rDTAA có thể gặp như hiện tượng rò (endoleak), thiếu máu tủy (liệt), đột quy, nhồi máu cơ tim cấp, suy hô hấp, lóc ngược động mạch chủ (lóc type $A)$, tiến tiển võ túi phồng tái phát sau can thiệp, suy thận, các biến chứng tại vị trí chọc mạch hay đường vào. Minami và cộng sự ${ }^{1}$ nghiên cứu trên 23 bệnh nhân điều trị rDTAA bằng TEVAR mạch thấy rằng tỷ lệ gặp biến chứng về hô hấp và các biến chứng nội sọ sau can thiệp cao (30,4\% và $26,1 \%), 17,4 \%$ có hiện tượng endoleak (1 trường hợp endoleak type I và 3 trường hợp type II). Tác giả báo cáo 1 trường hợp tử vong trong vòng 30 ngày $(4,3 \%)$, tuy nhiên tỷ lệ tử vong nội viện là 21,7\% (trong vòng 60 ngày). Các nguyên nhân tử vong được kể đến bao gồm: 1 bệnh nhân có tình trạng sốc trước can thiệp và cần cấp cứu ngừng tuần hoàn trong lúc can thiệp (bệnh nhân tử vong sớm sau can thiệp); endoleak type I (1 bệnh nhân - tử vong sau 60 ngày); 2 trường hợp có sốc trước can thiệp và tràn máu màng phổi tiến triển, các trường hợp này sau đó đều tử vong do suy đa tạng sau can thiệp (ngày 35 và 40); 1 trường hợp tử vong do biến chứng thủng thực quản gây sổc nhiễm khuẩn (ngày 35$)^{1}$. Jonker và cộng sự ${ }^{4}$ đã tổng hợp kết quả từ 28 nghiên cứu với 224 bệnh nhân rDTAA, trong đó 143 trường hợp 
được điều trị bằng TEVAR. Tác giả đưa ra kết quả trong nhóm sau TEVAR, tỷ lệ gặp endoleak là 10 ( 9 type I và 1 type II) trong 90 trường hợp $(11,1 \%)$, biến chứng nhồi máu cơ tim gặp $5 / 142$ trường hợp (3,5\%), đột quy gặp $5 / 123$ trường hợp $(4,1 \%)$, liệt tủy gặp 4/130 trường hợp $(3,1 \%)^{4}$. Tý lệ tử vong trong vòng 30 ngày là $18,9 \%$, các nguyên nhân chính bao gồm: mất máu nhiều, các biến chứng về tim, hoặc đột quy, suy đa tạng, nhiễm trùng, và các biến chứng hô hấp ${ }^{4}$. Hammo và cộng sự 5 nhiên cứu tổng hợp các kết quả điều trị rDTAA bằng TEVAR từ 6 trung tâm tại Thụy Điển trong vòng 15 năm với tổng số bệnh nhân là 140 trường hợp. Tác giả thây rằng tỷ lệ gặp các biến chứng sau mổ tới $44,9 \%$, các biến chứng chính bao gồm đột quy. $(14,7 \%)$, mất máu nặng $(9,6 \%)$, liệt tủy $(9,6 \%)$, biến chứng ở tim $(3,7 \%)$, suy thận $(3,7 \%)$. Tỷ lế gặp endoleak sau can thiệp là $22,1 \%$ (chủ yếu là type I) ${ }^{5}$. Tử vong sớm trong vòng 24 giờ và 30 ngày có tỷ lệ tương ứng là $10,7 \%$ và $20,7 \%$, các nguyên nhân được chỉ ra bao gồm các biến chứng tại động mạch chủ $(10 \%)$, tại tim $(3,6 \%)$, đột quy. $(2,9 \%)$, biến chứng hô hấp $(2,1 \%)$, nhiễm trùng $(0,7 \%)$, suy đa tạng $(0,7 \%)$, và võ lách $(0,7 \%)^{5}$. Etienne và cộng sự thông báo tỷ lệ gặp biến chứng sau can thiệp là $60 \%, 8$ trường hợp (32\%) có endoleak, các biến chứng khác bao gồm đột quỵ. (12\%), liệt tủy $(8 \%)$, võ̃ phồng tái phát, suy hô hấp, rò động mạch chủ thực quản, thiếu máu chi. Tỷ lệ tử vong trong 30 ngày là $36 \%$ do ngừng tim, vỡ phồng tái phát, suy đa tạng, rò động mạch - thực quản, suy hô hấp ${ }^{6}$. Tác giả cũng nhận xét rằng những trường hợp tử vong sớm thiên về nhóm trên 75 tuổi ${ }^{6}$. Tai Viêt Nam, Trần Tiến Quyết và Phan Duy Kiên ${ }^{7}$ tổng kết 31 trường hợp điều trị võ̃ phồng động mạch chủ ngực đoạn xuống tại Bệnh viện Chợ Rẫy từ năm 2012 đến năm 2019 cho kết quả tỷ lệ tử vong trong vòng 30 ngày là $31 \%$. Tác giả cũng ghi nhận tỷ lệ endoleak là 20,6\%, toàn bộ là type II, tác giả lý giải rằng che phủ động mạch dưới đòn trái là nguyên nhân của biến chứng này?

Các yếu tố liên quan đến tử vong sau can thiệ̂p bao gồm tuổi cao, tiền sử đột quyy, tiền sử phẩu thuật tai động mạch chủ, cũng như các đặc điểm sau mổ như chảy máu nhiêu, đột quy, suy thận ${ }^{5}$. Jonker và cộng sự cho rằng các yếu tố tiên lượng nguy cơ tử vong sớm trong vòng 30 ngày bao gồm tình trạng sốc giảm thể tích và tràn máu màng phổi khi nhập viện. Bệnh nhân của chúng tôi là một trường hợp lớn tuổi (78 tuổi), có đặc điểm lẩm sàng nặng trước mổ với biểu hiện sốc giảm thể tích và tràn máu màng phổi nhiêu, suy thận nặng. Mặc dù kết quả sớm sau những giờ đâu là thuận lợi, sau can thiệp 18 giờ bệnh nhân có biểu hiện mất máu cấp, bệnh nhân đột ngột tụt huyết áp, nhợt trắng, mạch chậm dẩn rồi ngừng tim, hôn mê, dẫn lưu màng phổi trái trào ra máu đỏ số lượng nhiều (trên $1000 \mathrm{ml}$ ) trước khi ngừng tuần hoàn và tử vong. Chẩn đoán phù hợp trong tình huống này có lẽ là biến chứng võ̃ phồng động mạch chủ tái phát sớm sau can thiệp, chưa loại trừ khả năng tiến tiển lóc ngược động mạch chủ type $A$. Đáng tiếc chúng tôi không thể xác thực được chấn đoán do không thể tiến hành giải phẫu tử thi hay cũng như những bằng chứng về hình ảnh. Tác giả Jonker cho rằng nguyên nhân chính dẫn đến tiến triển võ của đoạn ĐMC đã đặt stent graft hoặc các đoạn động mạch liền kề là do endoleak type I, do khung đỡ của ống ghép nội mạch chọc vào thành động mach chủ, hoặc muộn hợn do nhiễm trùng ống ghép ${ }^{4}$. Các báo cáo cho thấy tỷ lệ biến chứng nặng và tử vong tập trung nhiều vào thời điểm sau phẫu thuật, nghiên cứu của Hammo và cộng sự cho thấy tỷ lệ tử vong trong vòng 24 giờ đầu đếu $10,7 \%{ }^{5}$, ngoài biện pháp theo dỗi sát và hồi sức tích cực, liệu có nên thực hiện đánh giá lại các bằng thăm dò hình ảnh về kết quả sau can thiệp trong thời gian này để phát hiện sớm và xử lý nguy cơ biến chứng, tuy nhiên điều cũng này gặp khó khăn về khả năng triển khai và nguy cơ đi kèm quá trình đánh giá.

\section{KẾT LUÂ̂N}

Võ phồng động mạch chủ ngực đoạn xuống là bệnh lý thảm khốc. Mặc dù điểu trị can thiệp nội mạch đã phát triển và trở thành lựa chọn đầu tay đối với bệnh lý này, đây vẫn là một phương pháp có nhiều nguy cơ cao. Những biển chứng sớm thường nặng nề với tỳ lệ tử vong cao, đặc biệt trong những ngày đầu sau can thiệp. Ngoài việc phải lựa chọn chiến lược can thiệp cấp cứu nhanh chóng và phù hợp, các phương án theo dõi, hồi sức sau can thiệp đóng vai trò vô cùng quan trọng. Việc đánh giá lại sớm có lẽ là cần thiết để kịp thời xử lý các biến chứng có thể gặp phải.

\section{TÀI LIÊU THAM KHẢO}

1. Minami $T$, Imoto $K$, Uchida $K$, et al. Thoracic endovascular aortic repair for ruptured descending thoracic aortic aneurysm. J Card Surg. 2015;30(2):163-169. doi:10.1111/jocs.12499

2. Harky A, Manu N, Nasiri RA, et al. Ruptured isolated descending thoracic aortic aneurysm: open or endovascular repair? Vessel Plus. 2018;2. doi:10.20517/2574-1209.2018.12 
3. 2014 ESC Guidelines on the diagnosis and treatment of aortic diseases | European Heart Journal | Oxford Academic. Accessed July 9, 2021. https://academic.oup.com/eurheartj/article/35/41/ 2873/407693?login=true

4. Jonker FHW, Trimarchi $S$, Verhagen HJM, Moll FL, Sumpio BE, Muhs BE. Meta-analysis of open versus endovascular repair for ruptured descending thoracic aortic aneurysm. J Vasc Surg. 2010;51(4):1026-1032, doi:10.1016/j.jvs.2009.10.103

5. Hammo $S$, Larzon $T$, Hultgren $R$, et al. Outcome After Endovascular Repair of Ruptured Descending Thoracic Aortic Aneurysm: A National Multicentre Study. Eur J Vasc Endovasc Surg. 2019; 57(6): 788-794. doi:10.1016/j.ejvs.2018.10.029
6. Etienne $H$, Majewski $M$, Cochennec $F$, Segaux L, Becquemin J-P. Emergency Endovascular Interventions for Ruptured Descending Thoracic Aortic Aneurysm. Ann Vasc Surg. 2017;39:160166. doi:10.1016/j.avsg.2016.06.041

7. Tien TQ, Kien PD. Kết quả can thiệp nội mạch cấp cứu điều trị vỡ phình đông mach chủ ngực đoạn xuống. Tạp Chí Phẫu Thuật Tim Mạch Và Lồng Ngực Viêtt Nam. 2021;31:12-20. doi:10.47972/vjcts.v331i.497

8. Jonker FHW, Verhagen HJM, Lin PH, et al. Outcomes of endovascular repair of ruptured descending thoracic aortic aneurysms. Circulation. 2010;121(25):2718-2723.

doi:10.1161/CIRCULATIONAHA.109.908871

\title{
GIÁ TRI XÉT NGHIÊM FRUCTOSAMIN HUYẾT THANH TRONG PHẢN ÁNH ĐƯỜNG HUYẾT LÚC ĐÓI Ở BÊ̂NH NHÂN ĐÁI THÁO ĐƯỜNG CÓ BỆNH THẬN MẠN
}

\author{
Đào Thị Thúy*, Nguyễn Thị Băng Sương*, \\ Vũ Quang Huy*, Đoàn Thanh Hải*, Hà Mạnh Tuấn*.
}

\section{TÓM TẮT}

Mục tiêu: 1) Xác định nồng độ Fructosamin huyết thanh ở bệnh nhân đái tháo đường có bệnh thận mạn tính. 2) Xác đinh mối liên quan giữa nồng đô Fructosamin huyết thanh với đường huyết lúc đói và nồng độ $\mathrm{HbA1C}$ ở bệnh nhân đái tháo đường có bệnh thận mạn tính. Phương pháp nghiên cứu: Nghiên cứu bênh chứng. 136 bểnh nhân được đưa vào nghiên cứu chia thành 3 nhóm: nhóm bệnh nhân đái tháo đường có mức loc cầu thận (MLCT) $<60 \mathrm{ml} / \mathrm{p}$ (nhóm đái tháo đường bệnh thận mạn-ĐTĐBTM), nhóm bệnh nhân đái tháo đường có $\mathrm{MLCT} \geq 60 \mathrm{ml} / \mathrm{p}$ (nhóm đái tháo đường không bệnh thận mạn- ĐTĐKBTM) và nhóm người khỏe mạnh (NKM). Tất cả các bệnh nhân đều được định lượng Fructosamin huyết thanh, đường huyết lúc đói, HbA1C và các chỉ số sinh hóa có liên quan khác. Kết quả: Có 136 bệnh nhân được đưa vào nghiên cứu, trong đó có 50 bệnh nhân thuộc nhóm ĐTĐBTM, 56 bênh nhân ĐTĐKBTM và 30 bênh nhân thuộc NKM. Nồng độ Frucosamin huyết thanh trung bình ở nhóm ĐTĐBTM là $316.1 \pm 53.2 \mu \mathrm{mo} / \mathrm{l}$, cao hơn so với NKM là $60 \pm 27.4 \mu \mathrm{mo} / \mathrm{l}(\mathrm{p}<0.05)$; thấp hơn so với nhóm ĐTĐKBTM là $22.4 \pm 39.4 \mu \mathrm{mo} / \mathrm{l}$, tuy nhiên không có ý nghĩa thống kê $(p>0.05)$. Nồng độ Fructosamin huyết thanh không bị ảnh hưởng bởi Creatinin huyết thanh và $\mathrm{Hb}$. Nồng độ Fructosamin huyết thanh có mối tương quan thuận mức độ vửa với HbA1C ở nhóm ĐTĐBTM ( $r=0.388)$; và có mối tương quan thuận với nồng độ đường huyết lúc đói và

* Đai hoc Y Dước Thành Phố Hồ Chí Minh

Chịu trách nhiệm chính: Hà Mạnh Tuấn

Email: hamanhtuan@ump.edu.vn

Ngày nhận bài: 11.5.2021

Ngày phản biên khoa hoc: 28.6.2021

Ngày duyệt bài: 12.7.2021
HbA1C ở nhóm ĐTĐKBTM ( $r=0.487, r=0.466)$. Kết luận: (1) Nồng độ Fructosamin huyết thanh có mối tưởng quan thuận với nồng độ đường huyết lúc đói và HbA1C ở bệnh nhân đái tháo đường có bệnh thận mạn. (2) Nổng độ Fructosamin huyết thanh phản ánh được đường huyết lúc đói bệnh nhân đái tháo đường bệnh có bệnh thận mạn và không bị ảnh hưởng bởi các yếu tố suy thận, thiếu máu, nên là xét nghiệm có thể được dùng trong theo dõi và kiểm soát đường huyết ở bệnh nhân bệnh thận mạn.

Tư khóa: Đái tháo đường, bệnh thận mạn, Fructosamin, HbA1C.

\section{SUMMARY}

VALUE OF SERUM FRUCTOSAMIN IN REFLECTING FASTING GLUCOSE IN DIABETES MELLITUS WITH CHRONIC KIDNEY DISEASE

Objective: 1) Determine serum fructosamin concentration in diabetic patients with chronic kidney disease. 2) Determine the relationship between serum fructosamin concentration with fasting blood glucose and $\mathrm{HbA} 1 \mathrm{C}$ concentration in diabetic patients with chronic kidney disease. Methods: A case control study was conducted with 3 groups: a group of diabetic patients with glomerular filtration rate $<60 \mathrm{ml} / \mathrm{p}$ (diabetic group with chronic kidney disease), a group of diabetic patients with glomerular filtration rate $\geq 60 \mathrm{ml} / \mathrm{p}$ (diabetes without chronic kidney disease) and a group of healthy people. All patients have serum fructosamin, fasting blood glucose, $\mathrm{HbA1C}$ and other relevant biochemical parameteres measured. Results: There were 136 patients included into 3 groups: 50 diabetic patients with chronic kidney disease, 56 diabetic patients without chronic kidney disease and a healthy group of 30 people. (1) The mean concentration of Frucosamine in the diabetic group with chronic kidney disease was $316.1 \pm 53.2$ 